Available Online : https://proceeding.researchsynergypress.com/index.php/cset/index

RSF Conference Series: Engineering and Technology

ISSN 2809-6843 (Online) | 2809-6878 (Print)

Volume 1 Number 1 (2021): 545-548

\title{
Arjuna Coffee Organoleptic Test
}

\author{
Sari Virgawati1, Ari Wijayani', Ninik Probosari² \\ ${ }^{1}$ Department of Agrotechnology, Faculty of Agriculture, UPN Veteran Yogyakarta, Indonesia \\ ${ }^{2}$ Department of Management, Faculty of Economic and Bisnis, UPN Veteran Yogyakarta, Indonesia
}

\begin{abstract}
The organoleptic test of coffee grown in the Toyomarto area aims to determine consumer preferences for coffee grown on the slopes of Mount Arjuna. The two types of coffee that are most in demand in the global market are Arabica and Robusta. When viewed from the level of consumption, around 70\% of the world's population are consumers of Arabica coffee, which has a mild and aromatic taste. Meanwhile, the remaining 30\% of the world's population are consumers of Robusta coffee, whichhas a bitter taste and 50\% higher caffeine content than Arabica coffee. There is another type that is grown in Toyomarto, namely the Liberica type. Toyomarto Village, which is located in Singosari District, Malang Regency, is located at an altitude of 700-1200 masl. has a fertile soil that makes a specific and unique taste in the coffee that grows around it. Organoleptic testing has been carried out at 2 different locations. The panelists really liked the sour taste of Arabica coffee and the bitter taste of Robusta coffee. Meanwhile, Liberica coffee was less liked by the panelists.
\end{abstract}

Keywords: organoleptic test, Arabica coffee, Robusta coffee, Liberica coffee

\section{INTRODUCTION}

This is an open access article under the CC-BY-NC license

Coffee is a plant that thrives in tropical-sub-tropical regions. Indonesia is in a tropical climate so coffee plants can grow well. One of the areas suitable for coffee cultivation is the slopes of Mount Arjuna, East Java. Mount Arjuna is under the management of the Raden Soerjo Grand Forest Park, which is surrounded by Batu City, Malang Regency, and Pasuruan Regency (Direktur Jenderal Perkebunan, 2018). The two types of coffee that are most in demand in the global market are Arabica and Robusta. When viewed from the level of consumption, around $70 \%$ of the world's population are consumers of Arabica coffee, which has a mild and aromatic taste. While the remaining 30\% of the world's population are consumers of robusta coffee, which has a bitter taste and 50\% higher caffeine content than Arabica coffee (Birdieni, 2018; Hendri, Yusmanizar and Maulana, 2013). In addition, another type of coffee is Liberica. According to Pimenta (2009) organoleptic testing is a test based on the sensing process. Sensing is defined as a physio-psychological process, namely awareness or the introduction of the senses to the properties of objects due to the stimuli received by the senses originating from the object. Panelists were asked for their personal responses about their likes or dislikes (dislikes). In addition to the panelists expressed a happy response, like it or the opposite, they also expressed their level of preference. These levels of preference are called the hedonic scale. Arabica, Robusta and Liberica coffees have their own markets and each person will have a different level of preference (Mulato, 2002).

\section{LITERATURE REVIEW}

The Arjuna mountain area also has a famous type of coffee, namely Arjuna coffee. Most of the coffee plants found in the Arjuna mountain forest area are arabica coffee types while the rest are robusta coffee. Arjuna coffee is grown under stands including pine and mahogany but mostly covered by pine by $90 \%$ and mahogany trees around 10\% (Direktur Jenderal Perkebunan, 2018). Processing of coffee before it can be drunk goes through a long process, namely from harvesting ripe coffee beans either by machine or by hand, then processing the coffee beans and drying them before becoming coffee logs. The next process is roasting with varying degrees. After roasting, the coffee beans are ground or ground into coffee powder before the coffee can be drunk (Oktadina and Drefin, 2013). To determine the quality of coffee, it is necessary to do a taste test which is usually carried out by experts, a taste test is also called an organoleptic test (Permentan RI No. 50, 2012).

Measurement of the value / level of impression, awareness and attitude is called subjective measurement or subjective assessment. It is called a subjective assessment because the results of the assessment or 
measurement are largely determined by the perpetrator or the person taking the measurement. Stimuli that can be sensed can be mechanical (pressure, puncture), physical (cold, heat, light, color), chemical properties (smell, aroma, taste). When the sense organs receive a stimulus, before awareness occurs, the process is physiological, that is, it starts at the receptor and is transmitted to the sensory nervous system or reception nerves. The sensing mechanism in a nutshell is initiated by the reception of stimuli (stimulus) by special sensitive cells in the senses. Furthermore, reactions occur in sensitive cells to form chemical energy (Wijayani and Muafi, 2016).

According to Pimenta (2009), the aroma of coffee arises as a result of volatile compounds caught by the human sense of smell. Volatile compounds that affect the aroma of roasted coffee are formed from the Maillard reaction or non-enzymatic browning reaction, amino acid degradation, sugar degradation, and degradation of phenolic compounds. Besides being influenced by the roasting process, Ummah (2012) revealed that coffee has a very sharp and distinctive aroma, coupled with the heating or roasting process, it causes color changes and forms a more specific aroma. The taste of the organoleptic test showed that the average coffee taste was less bitter to bitter. Oktadina and Drefin (2013) revealed that the roasting process forms the distinctive aroma and taste of coffee due to heat treatment. So the longer the roasting time, the better the coffee taste will be. Most of the panelists said that in Arabica coffee, coffee was more likely to taste sour and less bitter. On the other hand, Robusta coffee tends to taste bitter and and less sour.

\section{RESEARCH METHODOLOGY}

The research object area is Toyomarto, Singosari District, Malang Regency, East Java. The research area has an altitude of 700-1400 meters above sea level. The method used in this study uses a qualitative descriptive method. Qualitative researchers emphasize process and meaning rather than quantity, frequency or intensity (which can be measured mathematically), but researchers will also conduct

descriptive statistical analysis in the form of frequency distribution or percentage to complete the data analysis.

The preference test is also known as the hedonic test. Panelists were asked for their personal responses about their likes or dislikes (dislikes). In addition to the panelists expressed a happy response, like it or the opposite, they also expressed their level of preference. These levels of preference are called the hedonic scale. For example, in terms of "like" it can have a hedonic scale such as: very much like, very like, like, somewhat like. On the other hand, if the response "does not like" can have a hedonic scale such as likes and somewhat likes, there is a response that is referred to as neutral, which is neither like nor dislike (neither like nor dislike). The scores referred to are as follows:

Table 1. Seven point of Hedonic Scale for Sensory Evaluation of Toyomarto Coffee

\begin{tabular}{|l|c|}
\hline Grade & Score \\
\hline Like extremely & 7 \\
\hline Like very much & 6 \\
\hline Like moderately & 5 \\
\hline Like slightly & 4 \\
\hline Dislike slightly & 3 \\
\hline Dislike moderately & 2 \\
\hline Dislike very much & 1 \\
\hline
\end{tabular}

As for the organoleptic test using 5 criteria, namely:

1. Fragrance that appears when the coffee beans are ground and not yet brewed.

2. Aroma or fragrance that appears when coffee beans are brewed with water.

3. Body or liquid coffee texture when in the mouth touches the tongue and upper wall of the mouth.

4. Acidity or "fruit acid" character that leads us to various the character of the coffee taste that is sipped.

5. After taste or traces of taste that impress us when drinking coffee even though we haven't had a sip. 


\section{FINDING AND DISCUSSION}

Panelists were asked for their personal responses about their likes or dislikes. In addition to the panelists expressed a response, like it or the opposite, they also expressed their level of preference. These levels of preference are called the hedonic scale. For example, in terms of "like" it can have a hedonic scale such as: like very much like, like slightly, or dislike very much, etc. The results of the taste test are asfollows:

Table 2. Organoleptic test of 3 types of Arjuna Coffee (\%)

\begin{tabular}{|c|c|c|c|c|c|c|c|}
\hline \multicolumn{8}{|c|}{ Criteria of Hedonic Scale } \\
\hline \multirow{2}{*}{$\begin{array}{l}\text { Organoleptic } \\
\text { test }\end{array}$} & 1 & 2 & 3 & 4 & 5 & 6 & 7 \\
\hline & \begin{tabular}{|l} 
Dislike \\
very much
\end{tabular} & $\begin{array}{l}\text { Dislike } \\
\text { moderatly }\end{array}$ & $\begin{array}{l}\text { Dislike } \\
\text { slightly }\end{array}$ & $\begin{array}{l}\text { Like } \\
\text { slightly }\end{array}$ & $\begin{array}{l}\text { Like } \\
\text { moderatly }\end{array}$ & $\begin{array}{l}\text { Like very } \\
\text { much }\end{array}$ & $\begin{array}{l}\text { Like } \\
\text { extremely }\end{array}$ \\
\hline ARABICA & \multicolumn{7}{|c|}{ Percentage (\%) } \\
\hline Sour & & & & & & & 100 \\
\hline Bitter & 5 & 5 & 80 & 10 & & & \\
\hline Fruity & & 5 & 5 & 40 & 50 & & \\
\hline Salty & 60 & 10 & 10 & 10 & 10 & & \\
\hline Fragrance & & & & 10 & 10 & 60 & 20 \\
\hline Texture & & & & 10 & 50 & 30 & 10 \\
\hline ROBUSTA & \multicolumn{7}{|c|}{ Percentage (\%) } \\
\hline Sour & 20 & 10 & 30 & 40 & & & \\
\hline Bitter & & & & & & & 100 \\
\hline Fruity & & & & 50 & 50 & & \\
\hline Salty & & & & & 70 & 30 & \\
\hline Fragrance & & & & & & 90 & 10 \\
\hline Texture & & & 80 & 20 & & & \\
\hline LIBERICA & \multicolumn{7}{|c|}{ Percentage (\%) } \\
\hline Sour & & & 90 & 10 & & & \\
\hline Bitter & & & 90 & 10 & & & \\
\hline Fruity & & & 90 & 10 & & & \\
\hline Salty & & & 40 & 60 & & & \\
\hline Fragrance & & & 40 & 60 & & & \\
\hline Texture & & 40 & 60 & & & & \\
\hline
\end{tabular}

Notes: the data was observed descriptively from 50 panelists at 2 locations.

From table 2, it can be seen that the sour taste of Arabica coffee grown in Toyomarto was liked extremely by $100 \%$ of the panelists, while there was a slightly sour taste preferred, i.e. $40 \%$ dislike slightly the bitter taste, $50 \%$ likes the fruity taste and $60 \%$ dislike the salty taste very much. While the aroma that appears when the Arabica coffee was freshly brewed and inhaled, $60 \%$ likes it very much and $20 \%$ extremely likes it, $10 \%$ likes moderately and likes slightly. The liquid coffee texture is the texture that is felt when the coffee is in the mouth and touches the tongue and the upper wall of the mouth. Arabica coffee was liked by $50 \%$ of the panelists, $30 \%$ liked it very much and $10 \%$ liked it extremely, while $10 \%$ liked itslightly.

Robusta coffee which is the largest variety that grows in Toyomarto, $100 \%$ of the panelists like extremely their bitter taste, $80 \%$ dislike slightly the sour taste, $50 \%$ likes the fruity taste and $50 \%$ likes it slightly. While $70 \%$ of panelists like the salty taste, $30 \%$ like it very much. The aroma that appears when the coffee was freshly brewed and inhaled, $90 \%$ like it very much and $10 \%$ extremely like it. $80 \%$ of the panelists disliked slightly the liquid texture of Robusta coffee, while $20 \%$ slightly like it.

Liberica coffee is rarely grown in Toyomarto, but to meet certain people's tastes, Liberica coffee is cultivated in several places. On average, the panelists did not like the sour, bitter, and fruity taste as much as $90 \%$, while $10 \%$ slightly liked it. The salty taste appears in this Liberica coffee and was slightly liked by the panelists as much as $60 \%$, while $40 \%$ is slightly disliked. $60 \%$ of the panelists liked the fragrance and $40 \%$ disliked it somewhat. The texture of the liquid coffee is slightly disliked by $60 \%$ of the panelists, while $40 \%$ did not like it. 
The two most popular varieties of coffee in the market are Arabica and Robusta. When viewed from the level of preference of the panelists, all of them liked the sour taste of Arabica coffee and the bitter taste of Robusta. According to Pimenta (2009), the aroma of coffee arises as a result of volatile compounds caught by the human sense of smell. Volatile compounds that affect the aroma of roasted coffee are formed from the Maillard reaction or non-enzymatic browning reaction, amino acid degradation, sugar degradation, and degradation of phenolic compounds. Besides being influenced by the roasting process, Ummah (2012) revealed that coffee has a very sharp and distinctive aroma. The heating or roasting process causes a color change and forms a more specific aroma. The taste of the organoleptic test showed that the average coffee taste was less bitter than bitter.

Oktadina (2013) revealed that the roasting process forms coffee's distinctive aroma and taste due to heat treatment. So the longer the roasting time, the better the coffee taste will be. Most of the panelists said that in Arabica coffee, coffee was more likely to taste sour and less bitter. The reaction or impression caused by the stimulus can be in the form of an attitude to approach or stay away, liking or disliking the object that causes the stimulus. Awareness, impressions, and attitudes to stimuli are psychological reactions or subjective reactions. Measurement of the value/level of impression, awareness, and attitude is called subjective measurement or subjective assessment. It is called a subjective assessment because the results of the assessment or measurement are largely determined by the perpetrator or the person taking the measurement. Stimuli that can be sensed can be mechanical (pressure, puncture), physical (cold, heat, light, color), chemical properties (smell, aroma, taste). When the sense organs receive a stimulus before awareness occurs, the process is physiological, that is, it begins at the receptor and is transmitted to the sensory nervous system or reception nerves

\section{CONCLUSION AND FURTHER RESEARCH}

The panelists like very much the sour taste of Arabica coffee and the bitter taste of Robusta coffee. Liberica coffee was less preferred by the panelists.

\section{Acknowledgement}

The authors would like to thank the Institute for Research and Community Service at UPN Veteran Yogyakarta, Indonesia, for providing funds for this research.

\section{REFERENCES}

Birdieni, 2018, https://www.gatra.com/detail/news/313752 indonesia berpotensi memiliki 300 indikasi geografis kopi).

Direktorat Jenderal Perkebunan, 2018. Produktivitas Kopi di Indonesia tahun 2014-2018.

Mulato, Sri. 2002. "Kopi 2002 dengan tema Mewujudkan perkopian Nasional Yang Tangguh melalui Diversifikasi Usaha Berwawasan Lingkungan dalam Pengembangan Industri Kopi Bubuk Skala Kecil Untuk Meningkatkan Nilai Tambah Usaha Tani Kopi Rakyat". Simposium. Denpasar : Pusat Penelitian Kopi dan Kakao Indonesia.

Oktadina, Fiona Drefin, 2013. "Pemanfaatan Nanas (Annanas Comosus L. Merr) untuk Penurunan Kadar Kafein dan Perbaikan Cita Rasa Kopi (Coffea sp) dalam Pembuatan Kopi Bubuk”. Jurnal Keteknikan Pertanian Tropis dan Biosistem. 1 (3)

Permentan RI No. 50/Permentan/CT.140/8/2012 Pedoman Pengembangan Kawasan Pertanian

Pimenta, T. V; et al. 2009. "Roasting Processing of Dry Coffee Cherry Influence of Grain Shape and Temperature on Physical Chemical and Sensorial Grain Properties". B.CEPPA Curitiba. 27 (1).

Syah, Hendri; Yusmanizar; dan Oki Maulana. 2013. "Karakteristik Fisik Bubuk Kopi Arabika Hasil Penggilingan Mekanis dengan Penambahan Jagung dan Beras Ketan". Jurnal Teknologi dan Industri Pertanian Indonesia. 5 (1)

Wijayani, Ari and Muafi. 2016. In vitro regeneration of Chrysanthemum callus after gamma ray irradiation for its resistance for medium plains. Journal Information 9 (6A): 1813-1817. 